\title{
Arquitectura en tiempo presente. Lo moderno incluye lo contemporáneo Fabrizio Toppetti
}

\author{
Francisco Gómez Díaz
}

Javier Navarro de Pablos

Buenos Aires: Ediciones Infinito, 2019 3 tomos, 157 págs., $13 \times 21,5 \mathrm{~cm}$. ISBN: 978-987-3970-16-0
Boletín Académico.

Revista de Investigación y Arquitectura Contemporánea Journal of Research and Contemporary Architectur Escola Técnica Superior de Arquitectura da Coruña

Número · Number: 11 (2021) Páginas · Pages: $84-85$

Recibido - Received: 07.11.2020

Aceptado - Accepted: 28.05.2021

Publicado . Published: 31.12.2021

ISSN 0213-3474

eISSN 2173-6723

DOI: https://doi.org/10.17979/

bac.2021.11.0.7117

https://orcid.org/0000-0002-

1315-3087

https://orcid.org/0000-0002-

3983-6783

Este trabajo está autorizado por una Licencia Creative

Commons (CC BY-NC-SA) 4.0
¿Cómo ordenaría el mundo un extraterrestre que llegase a una Tierra deshabitada? ¿en base a qué tipo de familias clasificaría las casas, iglesias, los estadios, museos, calles y fábricas? ¿Reconocería en el Guggenheim de Bilbao las proporciones de las iglesias de Borromini y en las obras de Rem Koolhaas coincidencias lexicales con Le Corbusier?.

Así inaugura Fabrizio Toppetti su particular visión de la arquitectura, considerada una obra inacabada en constante transformación, imposible de segmentar en trozos de tiempo o contextos estilísticos. Arquitectura en tiempo presente: lo moderno incluye lo contemporáneo ofrece una mirada, como su título indica, en presente continuo, intentando alejarse de las premisas y los prejuicios arquitectónicos como si él mismo fuera ese alienígena que aterriza en un planeta de grandes edificios vacíos. Estas pinceladas apocalípticas -inspiradas en El mundo sin nosotros de Alan Weisman-contrastan con una narrativa concisa - "en arquitectura existen los hechos"- en la que proyectos, autores y lugares van apareciendo como un continuum. El paisaje cultural que resulta de la transformación de la materia en forma de arquitectura es una colección de objetos y espacios que responden a necesidades funcionales y simbólicas.

Con un comienzo en el que se duda de la dicotomía entre lo moderno y lo contemporáneo, Toppetti defiende la imposibilidad de limitar el presente como periodo autónomo. Lo contemporáneo no goza de extensión y, por lo tanto, cualquier ejercicio de clasificación historiográfica es estéril. Esta referencia velada a las ideas de Marc Augé, recogidas en Hacia una antropología de los tiempos contemporáneos, sirve para que el autor entienda su propia obra un conjunto de "consideraciones inoportunas,
How would an extraterrestrial arriving on an uninhabited Earth order the world? On the basis of what kind of families would he classify houses, churches, stadiums, museums, streets and factories? Would he recognise in the Guggenheim in Bilbao the proportions of Borromini's churches and in the works of Rem Koolhaas lexical coincidences with Le Corbusier?

This is how Fabrizio Toppetti begins his particular vision of architecture, considered an unfinished work in constant transformation, impossible to segment into chunks of time or stylistic contexts. Arquitectura en tiempo presente: lo moderno incluye lo contemporáneo offers a view, as its title indicates, in the present continuous, attempting to distance himself from architectural premises and prejudices as if he himself were that alien landing on a planet of large empty buildings. These apocalyptic brushstrokes -inspired by Alan Weisman's The World Without Us-contrast with a concise narrative - "in architecture there are facts"in which projects, authors and places appear as a continuum. The cultural landscape that results from the transformation of matter in the form of architecture is a collection of objects and spaces that respond to functional and symbolic needs.

At the beginning of the essay, Toppetti questions the dichotomy between the modern and the contemporary, defending the impossibility of limiting the present as an autonomous period. The contemporary does not enjoy extension and, therefore, any exercise in historiographical classification is sterile. This veiled reference to the ideas of Marc Augé, collected in An Anthropology for Contemporaneous Worlds, serves to make the author understand 
> Fig. 01. Richard Neutra con su esposa Dione, mediados de los años setenta.

Fig. 01. Richard Neutra with his wife Dione, mid-sixties.

1) Fig. 02. Le Corbusier, Casa Curutchet, La Plata, 1949/53; fotografia de Fabrizio Toppetti. Fig. 02. Le Corbusier, Curutched House, La Plata, 1949/53; photography by Fabrizio Toppetti. $\checkmark$ Portada Cove

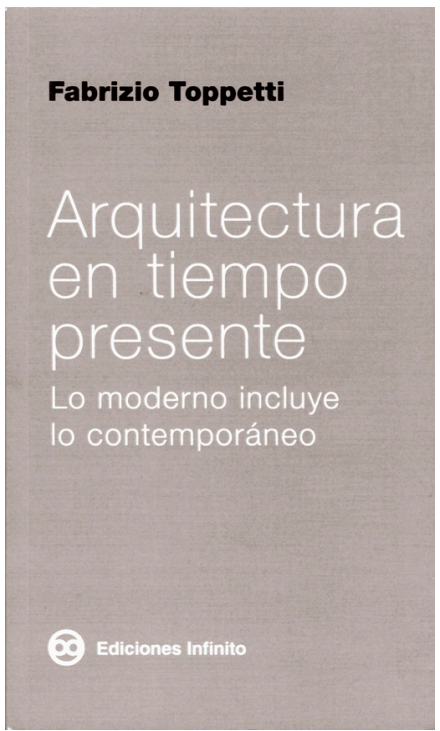

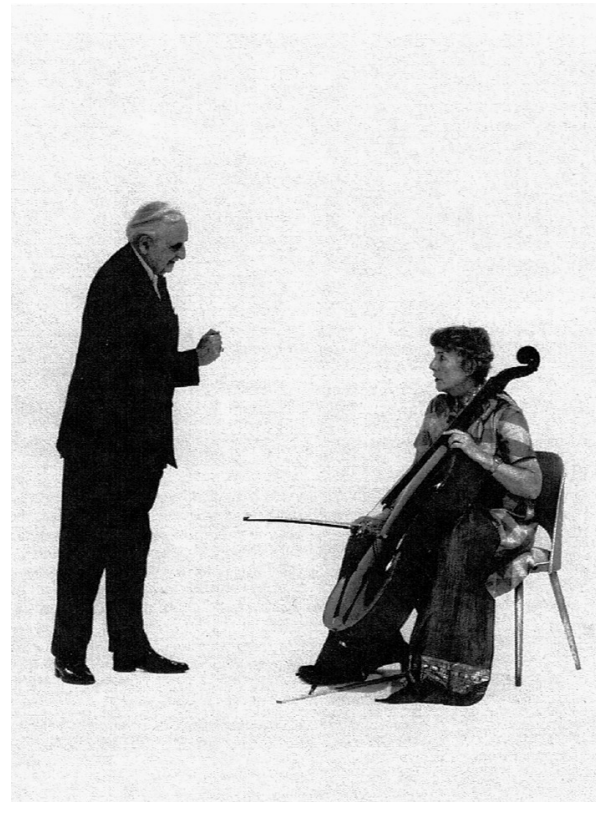

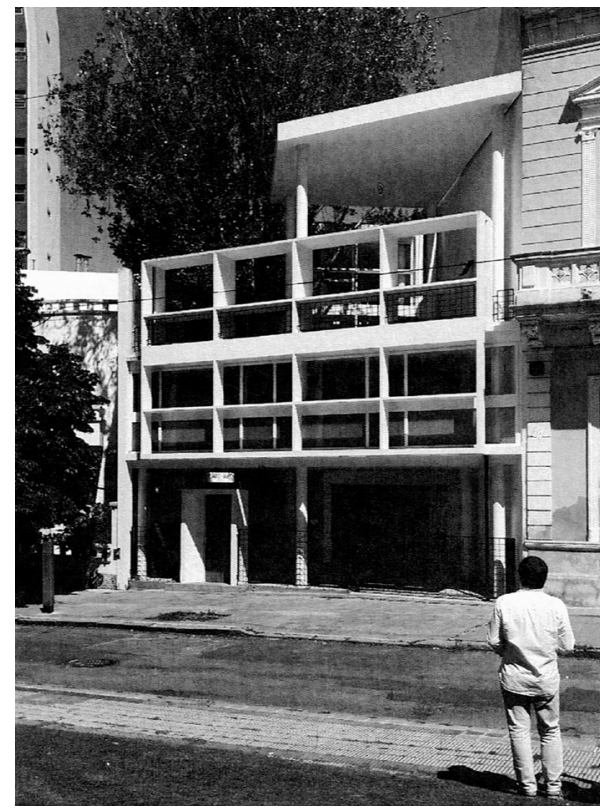

parciales y tendenciosas”. Liberado de una objetividad inalcanzable, Toppetti recorre el Dominion Center de Mies van der Rohe, el Banco de Londres y América del Sur de Clorindo Testa, las infraestructuras urbanas de Otto Wagner, las intervenciones sutiles de Dimitris Pikionis, o los ejercicios de modernidad contenida de Jozê Plecnik, apoyándose en textos de Giedion, Neutra o Zevi. Al trasluz, la cascada de referencias dibuja un panorama vital y sugestivo, una clara alternativa a la visión dogmática y segmentada de la crítica arquitectónica.

A través de la Casa Curutchet se trazan las analogías entre el bisturí de un médico y la necesidad de encontrar un instrumento icónico para los arquitectos, visibilizando el papel social de la arquitectura de la misma forma que el escalpelo es sinónimo de cura y progreso. El relato se cierra trazando escenarios abiertos como el concepto de espacio virtual, el equilibrio mediambiental o la revolución biopolítica, con el convencimiento de que la arquitectura alberga la solución a la ciudad a través de la "cultura del proyecto". A pesar del ejercicio propositivo, el autor reconoce el carácter impredecible del tiempo y sus hechos a través de una cita de Mies recogida en el número 1 de Bürohaus, dejando en suspenso cualquier intento de sistematizar lo contemporáneo: "La arquitectura es la voluntad de una época concebida espacialmente, viviente, en transformación, nueva. Ni al ayer, ni al mañana: solo es posible darle forma al hoy". his own work as a set of "inopportune, partial and tendentious considerations". Freed from an unattainable objectivity, Toppetti traces Mies van der Rohe's Dominion Center, Clorindo Testa's Bank of London and South America, Otto Wagner's urban infrastructures, Dimitris Pikionis's subtle interventions, or Jozê Plecnik's exercises in restrained modernity, relying on texts by Giedion, Neutra or Zevi. In the light, the cascade of references draws a vital and suggestive panorama, a clear alternative to the dogmatic and segmented vision of architectural criticism.

Through the Curutchet House, analogies are drawn between a doctor's scalpel and the need to find an iconic instrument for architects, making visible the social role of architecture in the same way that the scalpel is synonymous with healing and progress. The story closes by tracing open scenarios such as the concept of virtual space, environmental balance or the biopolitical revolution, with the conviction that architecture holds the solution to the city through the "culture of the project". In spite of the propositional exercise, the author recognises the unpredictable nature of time and its facts through a quote from Mies in issue 1 of Bürohaus, leaving in abeyance any attempt to systematise the contemporary: "Architecture is the will of a spatially conceived, living, changing, new epoch. Neither yesterday nor tomorrow: it is only possible to give form to today".

\section{Cómo citar $\cdot$ Citation}

Navarro de Pablos, Javier, y Francisco Gómez Díaz. Reseña de Arquitectura en tiempo presente. Lo moderno incluye lo contemporáneo, de Fabrizio Toppetti. BAC Boletín Académico. Revista de investigación y arquitectura contemporánea, no. 11 (2021): 84-85.

https://doi.org/10.17979/bac.2O2 1.11.0.7117. 